\title{
Impact of a Beehive on Cucumber Production Parameters (Number and Weight of Fruits) in Korhogo, Northern Côte d'Ivoire
}

\author{
TUO Yalamoussa ${ }^{1}$, COULIBALY Drissa ${ }^{1}$, KONE Mouhamadou $^{1}$, KONE Klana ${ }^{2}$, and KOUA Kouakou Hervé ${ }^{2}$ \\ 1 Peleforo Gon Coulibaly University, Faculty of Biological Sciences, Department of Animal Biology, BP 1328 Korhogo, Côte \\ d'Ivoire. \\ 2 Félix-Houphouët-Boigny University of Cocody (Abidjan Côte d'Ivoire), UFR Biosciences, Laboratory of Zoology and Animal \\ Biology, BP 1611 Abidjan 22, Côte d'Ivoire.
}

\begin{abstract}
This study was carried in two plots of cucumber cultivation. One located in the University garden and the other within a district of Korhogo. In the first plot, a beehive (Kenyan beehive) was installed contrary to the second plot where anything was done (used as control). The goal of this study was to contribute to the improvement of cucumber yield in Korhogo city. For that, the impact of a beehive colonized mainly by Apis mellifera, on cucumber production parameters, has been assessed. The production parameters measured in each plot were, bees' activity, the number and the weight of cucumber fruits. The beehive was installed to $30 \mathrm{~m}$ of the second cucumber plot. A total of 2380 bee specimens were recorded in the two experimental plots. Specifically, 1510 bee specimens $(63.45 \%)$ were recorded in the plot nearby beehive and 870 specimens $(36.55 \%)$ in the second plot without beehive. The average weight per fruit was $218.65 \mathrm{~g}$ in the plot nearby beehive and was $126.95 \mathrm{~g}$ in the plot without beehive. The average number of fruits was 18.1 in the plot nearby beehive against 9 in the plot without beehive. This study reveals a significant impact of bees on cucumber production parameters and will be very relevant in the resilience of farmer's systems.
\end{abstract}

Key words: Cucumber, Bees, Bees' activity, Beehive.

\section{INTRODUCTION}

Cucumber (Cucumis sativus L.) is a crawling annual herbaceous plant belonging to Cucurbitaceae family [1]. Coming from the Himalayas [2], fruits vary in shape, size and colour. They contain $0.40 \%$ of protein, $2.50 \%$ of carbohydrates, $1.50 \mathrm{mg}$ of iron and $2.00 \mathrm{mg}$ of vitamin $\mathrm{C}$ in $100 \mathrm{~g}$. Fruits consumption is recommended for people suffering from constipation, jaundice and indigestion [3]. Cucumbers are produced for their fruits that are consumed [4, 5]. One of the main factors of the good cucumber fruit production is the pollination service [4]. The cucumber is monoecious, the male and female flowers are separated on the same plant [5]. Cucumber pollination is mainly carried out by insects, particularly honey bees, Apis mellifera [4]. Pollinating insects are crucial to the optimal pollination of many crops, thus contributing to increased productivity and quality. This phenomenon is more important in Cucurbitaceae which are monoecious [6]. The implication of insects in the pollination of Cucurbitaceae has been established by several authors including Mc [7, 8]. In addition, according to Gingras and collaborators [9], cited by Delaplane and Mayer [10], most cucumber varieties require insects' presence for fruit set and yield increase. Thakur and Rana showed that cucumber pollination by bees resulted in a significantly higher percentage of healthy fruit than free and hand pollination [4]. Similarly, fruit weight, number of seeds per fruit, fruit size and, 1000 seeds weight were higher in bees' pollination compared to other pollination modes [4]. Ela and Messi reported that all fruits and seeds from unprotected female flowers of Cucumeropsis mannii were better than those from female flowers protected against pollinators [11]. According to these authors, the establishment of A. mellifera colonies and the conservation of wild honeycombs near the C. mannii field are recommended to improve yield. As cucumbers are of the same family than $C$. mannii, this study proposed to install a beehive of A. mellifera nearby a cucumber plot to assess it impact on the number and weight of fruits. 


\section{MATERIAL AND METHOD}

This study was carried out in two plots. One located in the garden of University and another in a district of Korhogo. In the garden of University, one beehive (Kenyan-type) was installed nearby a cucumber plot (ca. $30 \mathrm{~m}$ ), while neither beehive was installed in the second site so far from University (ca. $3 \mathrm{~km}$ ). The plant material used was "Poinsett"' cucumber variety, which was very popular in the different markets of Korhogo city.

\subsection{Experimental device}

In each study sites, the experimental setup was a completely randomized Fischer block. Four blocks were disposed in each experimental plot and each one was also composed of five elementary plots. A total of 20 elementary plots were used in all the study. The elementary plot consisted of four thick patches equidistant to $0.8 \mathrm{~m}$. The elementary plots $(3.2 \mathrm{x} 1) \mathrm{m}^{2}$ were distant to 1 $\mathrm{m}$, one another, and the blocks were distant to $2 \mathrm{~m}$. For the installation, hand ploughing, followed by levelling and picketing, and then adding one kilogram of ripe chicken manure to each poke was done one day before planting. Three seeds were sown per seed pack. One week after emergence, a demarcation was carried out, so to keep 1 plant per bunch. A total of 4 plants were planted in an elementary plot, for a total of 80 plants for each experimental site. In each site, two weeding operations were carried out during the entire cycle. Just before the first flower buds appearance, one kilogram of urea fertilizer was applied to each site. Before the first flower buds appearance in University site, the Kenyan beehive was prepared to capture a swarm of bees using natural attractants. The beehive was then hung on a tree $2 \mathrm{~m}$ above the ground to facilitate the capture of bees. Ten days after the empty, beehive was placed, it was colonized by a swarm of bees' mainly, A. mellifera. It was lowered then and placed $30 \mathrm{~m}$ from the plot on a $1 \mathrm{~m}$ high iron support to facilitate maintenance operations.

\subsection{Assessment of beehives impact on bees' activity}

This method was evaluated by counting bees foraging cucumber flowers from beginning the first flowers appearance to harvesting period. The observations were carry out twice a week between 5 am and 6 pm, in the both sites. As study realized by Hala and collaborators, during each time, 5 plants were randomly selected and, the flowers were observed for 10 minutes [12]. The number of bees foraging the flowers was recorded for each selected plants. At the same time, temperature and relative humidity were recorded per hour, allowing to assess the impact of these abiotic parameters on bees' activity.

\subsection{Assessment of beehives impact on the number and the weight of fruits}

The ripe fruits were harvested, counted and weighed though a scales to determine the weight of fruits.

\subsection{Data analysis}

Using Statistica software (version 7.1), the analysis of variances of the average number and weight of fruits was carried out in order to assess the impact of beehive on these production parameters. These analyses followed Newman-Keuls tests at the $5 \%$ threshold in the event of a significant difference. The calculation of correlation coefficients was used to assess the influence of temperature and relative humidity on the daily bees' activity.

\section{RESULTS}

\subsection{Assessment of beehive on the number of bees visiting the flowers}

Apis mellifera was more active in the botanical garden than in the peasant environment. A total of 2380 bee specimens were collected in the two sites. Specifically, 1510 specimens corresponding to $63.45 \%$ were recorded in the plot nearby beehive against 870 bee specimens $(36.55 \%)$ for the other plot without beehive (Figure 1).

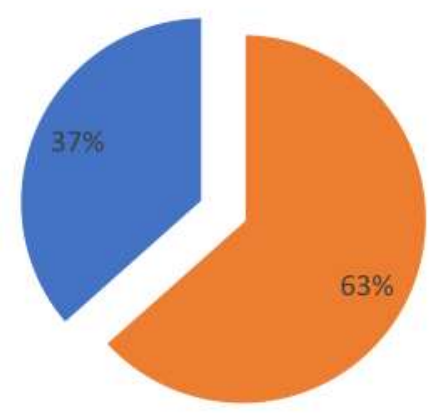

" plot with beehive

- plot without beehive

Figure 1: Proportion of Apis mellifera per site 


\subsection{Foraging behaviour of $A$. mellifera}

The number of A. mellifera visiting the flowers in the plot nearby beehive, varied in bell shape during the day. The peak of bees' activity was observed in morning at $6 \mathrm{am}$. Beyond this period, bees' activity decrease gradually to reach a minimum towards 4 pm, then increased again between 4 pm and 5 pm (Figure 2). In peasant environments where there was no beehive, the fluctuation in daily bees' activity was similar to that observed in the plot nearby beehive located in the botanical garden (Figure 2).

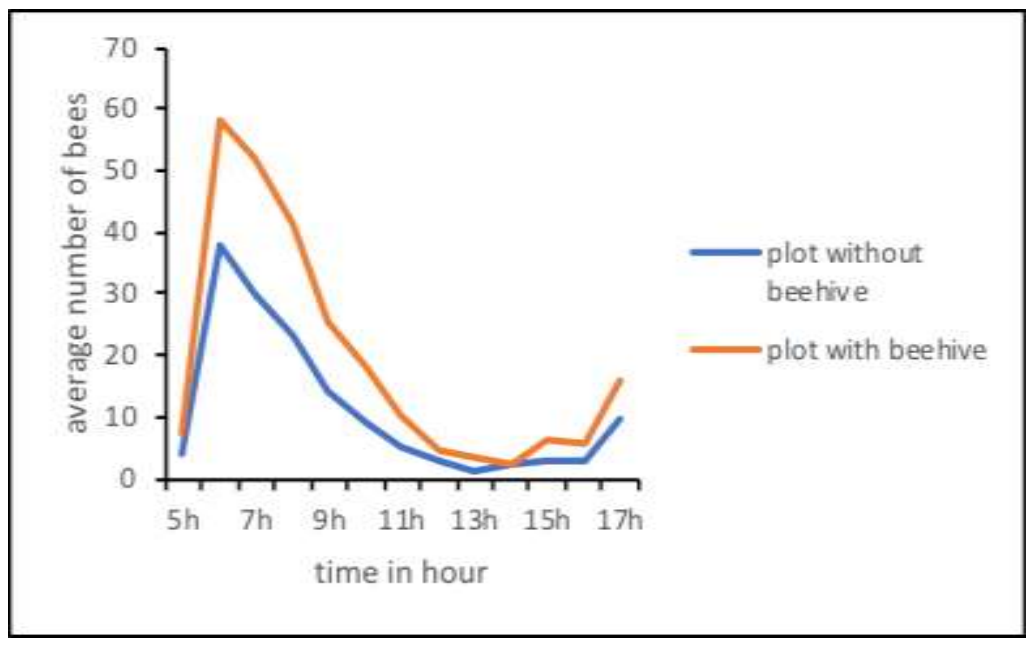

Figure 2. Bees' activity in the both sites

\subsection{Influence of meteorological parameters on bees' activity}

The daily activity curve of A. mellifera can be superimposed to that of relative humidity. In the two experimental plots, bees' activity increase with the relative humidity and vice versa (Figure 3$)$. The correlation $(r=0.89 ; \mathrm{p}<0.05)$ established between bees' activity and relative humidity was positive (Figure 4). At the opposite, bees' activity increase when the temperature decrease (Figure 5). There is a negative correlation $(r=-0.72 ; \mathrm{p}<0.05)$ between temperature and bees' activity (Figure 6).

\subsection{Impact of beehive on the number and weight of fruits}

Regarding the number of fruits, an average of $18.1 \pm 0.42$ fruits were harvested per elementary plot on the site nearby beehive compared to an average of $9 \pm 0.22$ fruits per elementary plot on the site without beehive. The analysis of variances revealed a significant difference $(\mathrm{p}<0.05)$ between the average numbers of fruits according to the type of association. The presence of beehive had a significant impact on the number of fruits produced. An average weight of $126.95 \pm 0.79 \mathrm{~g}$ were recorded in the site without beehive compared to an average weight of $218.65 \pm 0.65 \mathrm{~g}$ in the site with beehive. The analysis of variances revealed a significant difference $(\mathrm{p}<0.05)$ between the weight of fruit harvested in the plot nearby beehive and that without beehive. The presence of beehive in cucumber cultivation therefore had a significant impact on the weight of the fruits.

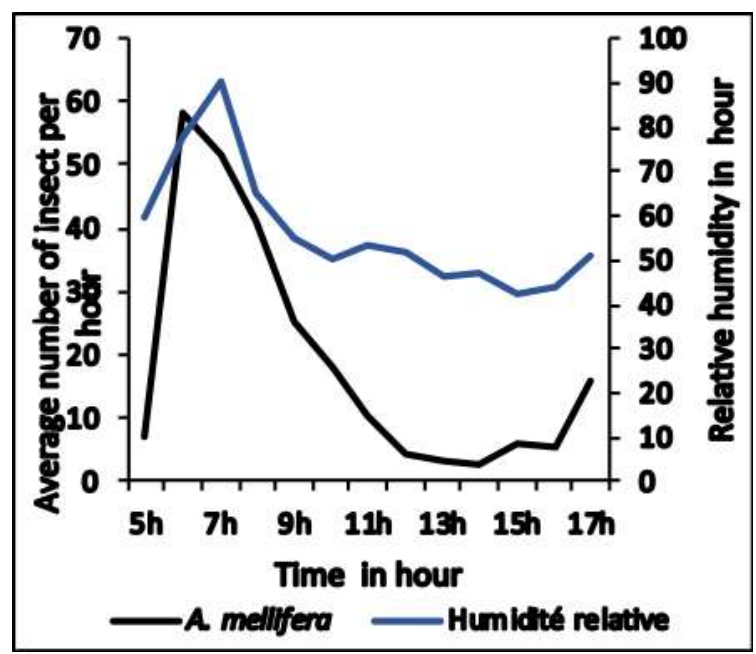

Figure 3. Fluctuation of bees' activity and the temperature on cucumber plot

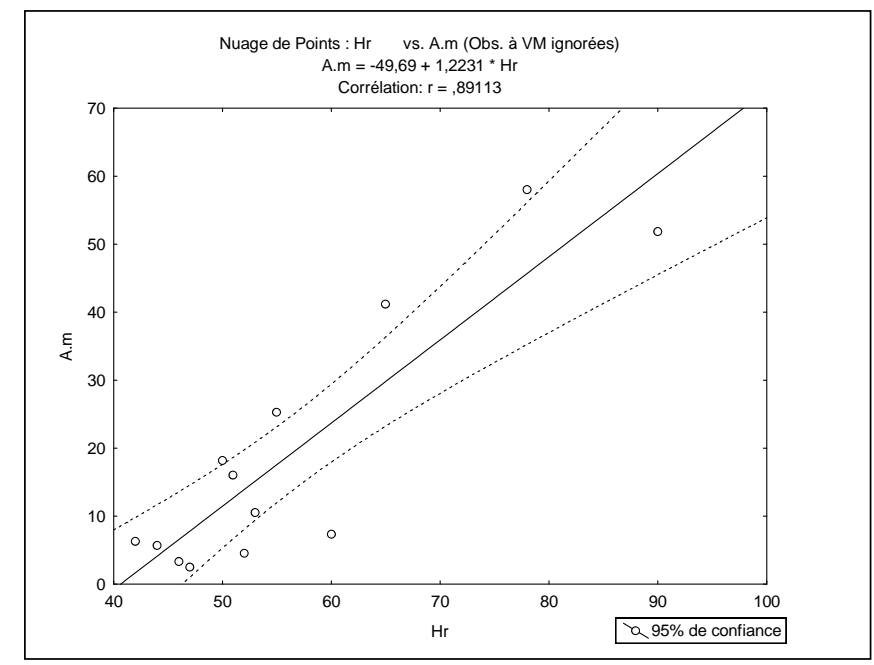

Figure 4. Correlation between relative humidity and bees' activity 


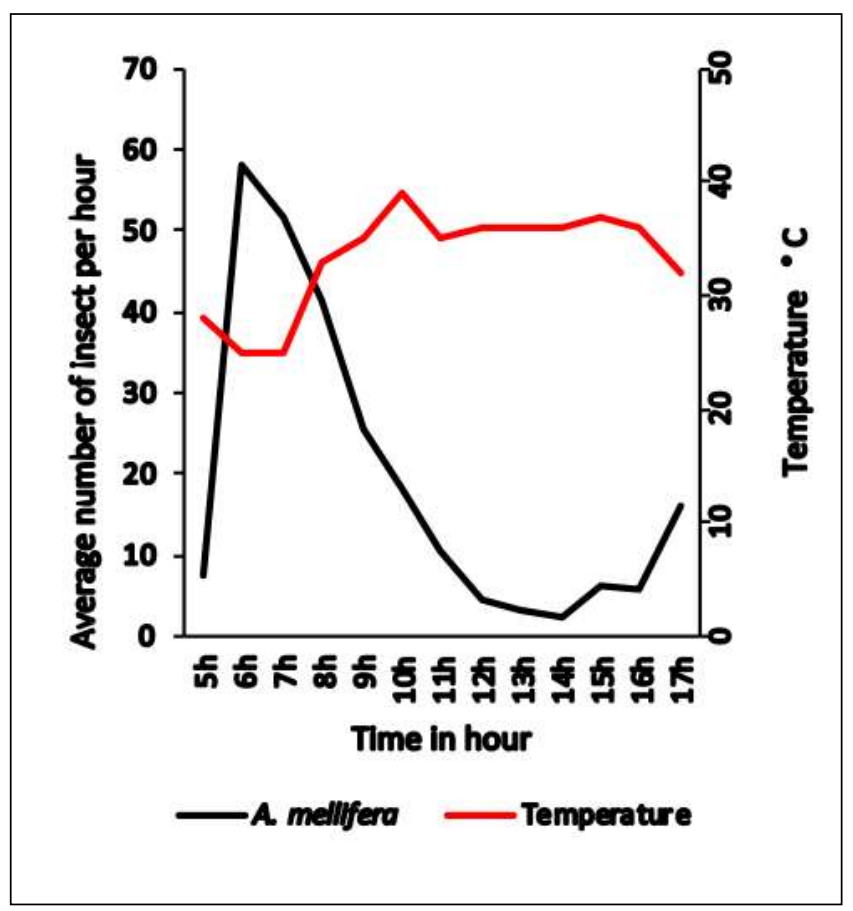

Figure 5. Fluctuation of bees' activity and the temperature on cucumber plot

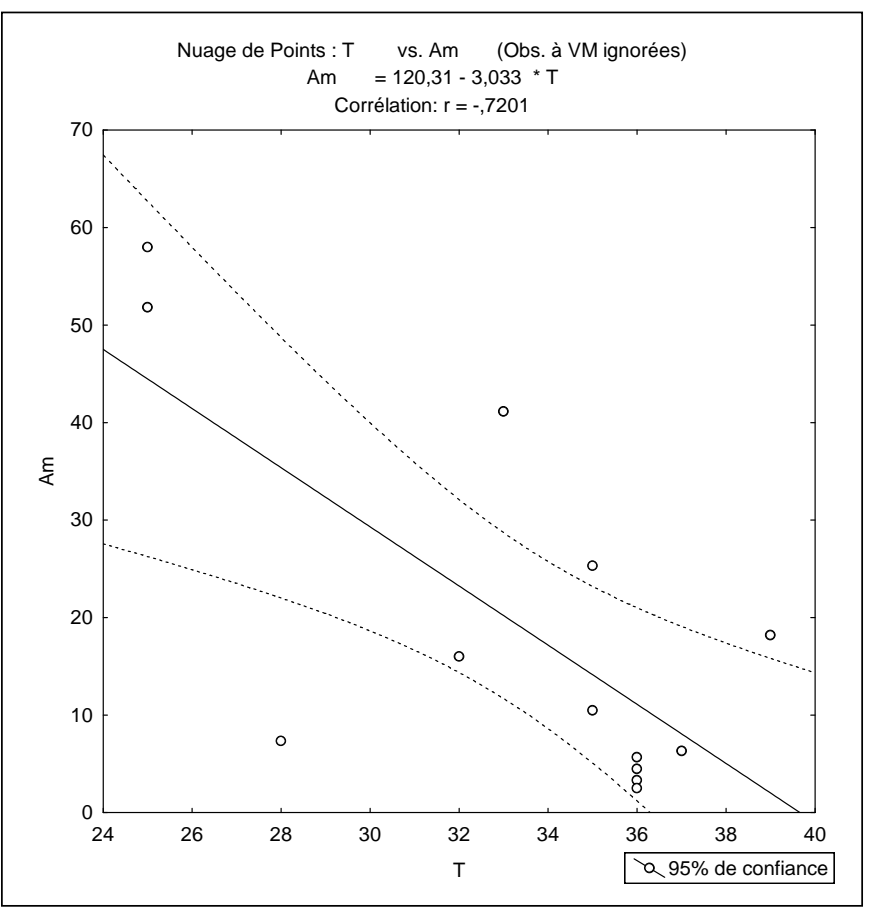

Figure 6. Correlation between temperature and bees' activity

\section{DISCUSSION}

This study assessed the impact of beehive nearby a cucumber plot. The analysis showed that A. mellifera is more active too early in morning $(6 \mathrm{am})$ and late in evening $(5 \mathrm{pm})$. The presence of bees on the flowers is not coincidental. Indeed, according to Corbet and collaborators, the presence of bees on flowers depends on the intensity of the fragrance released by the flowers [13]. Pollinating insects are looking for nectar as their food source. The production and quality of nectar varies according to the hour of the day, the age of the flower, the species and the weather conditions [14]. According to Tuo, most of insects' activity on oil palm inflorescences was observed between 9 am and $1 \mathrm{pm}$ with a peak at $11 \mathrm{am}$ on both the first and second day of anthesis [15]. This author reported that this time period coincides certainly with the period during which the aniseed scent released by the flower is potentiated by the blooming of a larger number of flowers. The morning and intense bees' activity is synchronized with maximum nectar secretion [16]. Delaplane and Mayer found also that nectar is the main resource harvested by bees visiting cucumbers [10]. The attraction of pollinators to inflorescences would be a function of the concentration of chemicals secreted by the flowers during their blooming. According to Pouvreau, the concentration of sugar in the liquid coating the surface of the stigmas of oil palm flowers is insufficient to attract insects from Apidae family [14]. They prefer flowers with a relatively high sugar concentration in nectar, such as Cucurbitaceae [13]. In cucumbers, this production is probably intensified very early in the morning at 6 am and late in the evening around $5 \mathrm{pm}$. Patten and collaborators reported that the highest frequency of bees foraging on cucumbers occurs at the beginning and the end of day [17]. As reported by Benachour, the most important peaks of bees' activity were recorded between $10 \mathrm{am}$ and 11 am [1]. According to Tchenguem and collaborators, bees forage maize throughout the day and throughout the flowering period, but their visits are more frequent in the morning and during the period of high anthesis [18]. Bees' activity was inversely proportional to the temperature fluctuation. This influence would be linked to the impact of this climatic factor on the flower's functioning. Indeed, according to Kropacova and Haslbachova [19] cited by Jakobsen and Kritjansson [20], there is a negative correlation between temperature and nectar secretion in Trifolium repens. For Albano and Salvano [21], at a low temperature between $20^{\circ} \mathrm{C}$ and $25^{\circ} \mathrm{C}$ and a constant relative light, the flowers take on a blooming state with easily extractive substances, which increases bees' activity. Abou-Shaara reported that the importance of temperature and relative humidity for honey bees is well known and that all activities of honey bees' colonies are under the control of these factors [22]. Temperature, in particular, is very important for the internal and external activities of honey bees' colonies. Ambient temperature has a significant effect on foraging, with high temperature negatively affecting bees' foraging [23, 24, 25]. During the hottest hours of the day, from 12 am to 3 pm, foragers spend less time on Dacryodes edulis flowers than during time slots (6 am to 9 am or $5 \mathrm{pm}$ to $7 \mathrm{pm}$ ) when the temperature is cooler [18]. The analyses showed that the frequency of bees' visits was positively correlated with the fluctuation of relative humidity. This correlation could be due to the fact that high relative humidity has a positive impact on bees' biology. According to Human and collaborators, high relative humidity is mainly required for brood development [26]. The effect of moisture on egg hatch rate has already been identified [27] and a relative humidity of about 75\% in the colonies could be considered suitable for the immature stages [28]. However, according to Joshi and Joshi, in the case of 
external activities, no clear direct impact of relative humidity on bees has been reported, including foraging activities [29]. Regarding the number and weight of fruits, they were higher in the vegetable square than in the peasant environment. This could be explained by the fact that bees' activity, due to the presence of beehive in University vegetable garden, was higher than that in a farming environment. As bees' activity on the flowers is crucial for setting, it is evident that production is high on plots with a high bees' activity. For Ndola and collaborators, the introduction of bee colonies in C. mannii crops has statistically improved the average number of seeds per fruit, the weight of seeds extracted per fruit and the average number of fruits per plant [30]. Such improvements have been also reported on colza and other Cucurbits by Azo'o and collaborators [31]. Dos Santos and collaborators have reported also an improvement in cucumber production in the plots with bee colonies [32].

\section{CONCLUSION}

It appears clearly in this study that bees' activity mainly honeybees, is higher in morning than afternoon on cucumber flowers. It is positively correlated with relative humidity and negatively correlated with temperature. The association of beehives with cucumber fields improves significantly the production parameters. It would therefore be important to train cucumber producers to set up beehives nearby their fields. In addition, it is necessary to determine the number of beehives in order to optimize the production.

\section{REFERENCES}

1. Benachour K., \& Louadi K., (2011). Comportement de butinage des abeilles (Hymenoptera: Apoidea) sur les fleurs mâles et femelles du concombre (Cucumis sativus L.)(Cucurbitaceae) en région de Constantine (Algérie). In Annales de la Société Entomologique de France, Vol. 47, No. 1-2, pp. 63-70.

2. Pinoit C., (2015). Analyse du climat dans les serres de concombre Comparaison entre site expérimental et site de productionMémoire de Fin d'études. Master 2 Sciences Technologie Santé Mention Biologie et Technologie du Végétal Spécialité : Production et Technologie du Végétal (ProTeV). Université Angers, 86 P.

3. Pateel M.C., (2007). Impact of honeybee pollination on qualitative and quantitative parameters of cucumber (Cucumis sativa L.) (Doctoral dissertation, UAS, Dharwad). 66p.

4. Thakur M., \& Rana R.S., (2008). Studies on the role of insect pollination on cucumber yield. Pest Technology. Global Science Books, 2(2): 130-133.

5. Hanh T.T.M., Sharma S.K., \& Rana M.K., (2014). Pollination Efficiency of Native Bee Pollinators of Cucumber (Cucumis sativus L.) in India. Journal of Apiculture, 29(3), 199-205.

6. Subhakar G., Sreedevi K., Manjula K., \& Reddy N.E., (2013). Pollinator diversity and abundance in bitter gourd, Momordica charantia Linn. Pest Management In Horticultural Ecosystems, 17(1), 23-27.

7. Mc Gregor S.E., (1976). Insect pollination of cultivated crops plants. US Department of Agriculture, Agriculture Handbook No 496, Washington, $411 \mathrm{p}$.

8. Free J.B., (1993). Insect Pollination of Crops.2nd Ed., Academic Press, London, 684pp.

9. Gingras D., de Oliveira D., \& Gingras J., (1996). Honey bees and the production of cucumbers in Quebec (Canada). In VII International Symposium on Pollination 437, pp. 395-400.

10. Delaplane K.S., \& Mayer D.F., (2000). Crop pollination by bees. CABI Publishing, Wallingford, UK and New York, 352 p.

11. Ela A.M., \& Messi J., (2012). Yield responses of Cucumeropsis mannii (Cucurbitaceae) to the presence or the absence of the insect foraging activity at Nkolbisson in Cameroon. J. Anim. Plant Sci, 13(3), 1791-1799.

12. Hala N., Tuo Y., Akpesse A.A.M., Koua H.K., \& Tano Y., (2012). Entomofauna of oil palm tree inflorescences at La Mé experimental station (Côte d'Ivoire). American Journal of Experimental Agriculture, 2(3), 306-319.

13. Corbet, S.A., Williams, I.H., \& Osborne, J.L., (1991). Bees and the pollination of crops and wild flowers in the European Community. Bee world, 72(2), 47-59.

14. Pouvreau A., (1984). Cultures tropicales oléagineuses. In : Pollinisation et production végétale (coordonné par PESSON P., LOUVEAUX J.), .INRA, Paris. 331-347.

15. Tuo Y., (2013). État de l'entomofaune des inflorescences du palmier à huile en côte d'ivoire : cas de la station CNRA de La Me, Thèse de doctorat de l'Université Felix Houphouët-Boigny, spécialité entomologie agricole, Laboratoire de zoologie, biologie animale et écologie. 204p.

16. Cervancia C.R., \& Bergonia E.A., (1990). Insect pollination of cucumber (Cucumis sativus L.) in the Philippines. In VI International Symposium on Pollination 288 (pp. 278-282).

17. Patten K.D., Shanks C.H., \& Mayer D.F., (1993). Evaluation of herbaceous plants for atractiveness to bumble bees for use near cranberry farm. Journal of apicultural ressearch, 32 (2), 73-79.

18. Tchenguem Fohouo F.N., Messi J., Pauly A., (2002). Activité de Meliponula erythra sur les fleurs de Dacryodes edulis et son impact sur la fructification. Fruits 56 (3) : 179-188. 
19. Kropacova S., Haslbachova H., (1970). A study of the effect of some climatic factors on nectar secretion in sainfoin (Onobrychis viciaefolia v. sativa Thell.) and white clover (Trifolium repens L.). Acta Universitatis Agriculturae, series A 18:613-620.

20. Jakobsen H.B., \& Kritjansson K., (1994). Influence of temperature and floret age on nectar secretion in Trifolium repens L. Annals of Botany, 74(4), 327-334.

21. Albano M., \& Salvano F., (2000). Influence of cropping season in foraging activity of bumblebee in greenhouse tomato crop, XXI international congress of entomology, August 20-26 ; Brazil, p. 43.

22. Abou-Shaara H.F., Al-Ghamdi A.A., \& Mohamed A.A., (2012). Tolerance of two honey bee races to various temperature and relative humidity gradients. Environmental and experimental Biology, 10(4), 133-138.

23. Cooper P.D., Schaffer W.M. (1985). Temperature regulation of honey bees (A. mellifera) foraging in the Sonoran desert. J. Exp. Biol. 114: 1-15.

24. Al-Qarni A.S., (2006). Tolerance of summer temperature in imported and indigenous honeybee A. mellifera L. races in central Saudi Arabia. Saudi J. Biol. Sci. 13: 123-127.

25. Blazyte-Cereskiene L., Vaitkeviciene G., Venskutonyte S., \& Buda V., (2010). Honey bee foraging in spring oilseed rape crops under high ambient temperature conditions. Zemdirbyste-Agriculture 97: 61-70.

26. Human H., Nicolson S.W., \& Dietemann V., (2006). Do honeybees, A. mellifera scutellata, regulate humidity in their nest? Naturwissenschaften 93: 397-401.

27. Doull K.M., (1976). The effects of different humidities on the hatching of the eggs of honeybees. Apidologie 7: 61-66.

28. Ellis M.B., Nicolson S.W., Crewe R.M., \& Dietemann V., (2008). Hygropreference and brood care in the honeybee $(A$. mellifera). J. Insect Physiol. 54: 1516-1521.

29. Joshi N.C., Joshi P.C. (2010). Foraging behaviour of Apis spp. on apple flowers in a subtropical environment. NY Sci. J. 3: 71-76.

30. Ndola B.P., Brostaux Y., Le Goff G., Susini M. L., Haubruge E., Francis F., \& Nguyen B.K., (2017). Effects of $A$. mellifera adansonii, L. 1758 (Apidae: Hymenoptera) pollination on yields of Cucumeropsis mannii (Naudin) in Kisangani, Democratic Republic of Congo. International Journal of Biological and Chemical Sciences, 11(2), 640-650.

31. Azo'o Ela M., Messi J., Tchuenguem Fohour F.N., Tamasse J.L., Kekeunou S., \& Chemetkov M.F., (1973). Utilisation des abeilles sous serre pour la pollinisation des concombres. Pchelovodstvo, 12, 4-7 (russe).

32. Dos Santos S.A., Roselino A.C., \& Bego L.R., (2008). Pollination of cucumber, Cucumis sativus L.(Cucurbitales: Cucurbitaceae), by the stingless bees Scaptotrigona aff. depilis moure and Nannotrigona testaceicornis Lepeletier (Hymenoptera: Meliponini) in greenhouses. Neotropical entomology, 37(5), 506-512. 